Table 1. Influence of the proximity of sod to young peach trees on the crotch angle of primary scaffold limbs.

\section{Proximity of Sod to Young Peach Trees Affects the Crotch Angle of Primary Scaffolds}

\author{
William V. Welker ${ }^{1}$ and D. Michael Glenn ${ }^{2}$ \\ U.S. Department of Agriculture, Agricultural Research Service, Appalachian \\ Fruit Research Station, Kearneysville, WV 25430
}

Additional index words. orchard floor management, vegetation-free area, Prunus persica

The crotch angle of main scaffold limbs of fruit trees is important in their management and productivity (Westwood, 1978). The tissues of narrow-angled crotches in apples (Malus domestica Borkh.) are more susceptible to winter injury and disease than are tissues in crotches formed by wide-angled branches (Horsfall, 1932). Scaffold limbs with narrow crotch angles are structurally weak and prone to breakage when carrying a heavy fruit load (Bukovac, 1963; Verner, 1938). Many cultural practices influence the crotch angles of main scaffold branches, including manual and various pruning techniques (Westwood, 1978). Warner (1991) found differences in the crotch angles of the primary scaffold branches of apples resulting from the rootstock.

In our orchard floor management studies (Welker and Glenn, 1991), we observed that the crotch angles of the main scaffold limbs of peach trees were affected by the tree's proximity to the grass sod. Those branches closest to the grass appeared more upright than those growing toward the bare soil. The objective of these studies was to evaluate the influence of sod proximity on the crotch angle of the primary scaffold limbs of young peach trees.

'Redhaven' peach trees (Prunus persica $\mathrm{L}$. Batsch.) on Halford seedling rootstock were trained to an open-center system with three main scaffold limbs. The crotch angles of the primary scaffold limbs were measured after the second growing season using an angle meter protractor. The values are expressed as degrees from the vertical (the larger the value,

Received for publication 26 Sept. 1994. Accepted for publication $23 \mathrm{Jan}$. 1995. The cost of publishing this paper was defrayed in part by the payment of page charges. Under postal regulations, this paper therefore must be hereby marked advertisement solely to indicate this fact.

${ }^{1}$ Weed Scientist.

${ }^{2}$ Soil Scientist. the wider the crotch angle). The design consisted of a randomized complete block with five replications. Each plot consisted of three trees that were grown in either an established Kentucky 31 (K-31) tall fescue (Festuca arundinacea Schreb) sod or in a $6.8-\mathrm{m}^{2}$ vegetation-free area within a K-31 sod. The vegetation-free area was arranged in either a $2.6 \times$ $2.6-\mathrm{m}$ square or in a $1.5 \times 4.5-\mathrm{m}$ strip (width/ length). The trees grown in the strip were located in the center of the vegetation-free strip. The trees grown in the square were located either in the center of the square or at one side (edge) of the square. Scaffold limbs on trees grown at one side of the square were separated into treatments (toward sod and toward bare soil). All trees were $4.5 \mathrm{~m}$ apart within rows spaced $6 \mathrm{~m}$ apart. In a similar study, 'Loring' on Lovell seedling rootstock was grown in the center of three sizes of vegetation-free squares $\left(2.3,4.4\right.$, and $\left.7.3 \mathrm{~m}^{2}\right)$ within an established K-31 sod in a randomized complete-block design with five replications.

'Redhaven' trees grown in the center of the vegetation-free square had the widest crotch angles, whereas those grown in sod had the narrowest crotch angles (Table 1). When the trees were grown at the edge of a vegetationfree square, those limbs growing toward the grass sod had narrower crotch angles than those growing toward the vegetation-free area.

In the 'Loring' study, the crotch angle was widest in those trees grown in the largest vegetation-free areas and narrowest in those trees grown in the smallest vegetation-free area (Table 1).

These studies show that vegetation management of the orchard floor can impact the structure of a young peach tree. The closer the grass sod was to the tree, the more upright the scaffold limbs grew. K-31 sod reduces peach root growth (Glenn and Welker, 1993; Parker et al., 1993). Root tissue and specifically the root tips are a primary source of cytokinins

\begin{tabular}{lc}
\hline $\begin{array}{l}\text { Cultivar and } \\
\text { tree location }\end{array}$ & $\begin{array}{c}\mathrm{Crotch}^{2} \\
\text { angle }\left(^{\circ}\right)\end{array}$ \\
\hline Redhaven/Lovell & \\
Center of square & $52 \mathrm{a}$ \\
Center of strip & $45 \mathrm{~b}$ \\
Edge of square & \\
$\quad$ Toward sod & $37 \mathrm{c}$ \\
$\quad$ Toward bare soil & $50 \mathrm{a}$ \\
Sod & $25 \mathrm{~d}$ \\
Loring/Halford & \\
Vegetation-free area $\left(\mathrm{m}^{2}\right)$ & \\
7.3 & $63 \mathrm{a}$ \\
4.4 & $48 \mathrm{~b}$ \\
2.3 & $39 \mathrm{c}$
\end{tabular}

${ }^{2}$ Means separated within columns by Duncan's multiple range test, $P \leq 0.05$.

(Skene, 1975) in plants. The reduction in root growth due to the proximity of sod may reduce endogenous cytokinin levels, thus possibly altering the growth habit and canopy structure of peach, as is the case with apples (Williams and Billingsley, 1970).

\section{Literature Cited}

Bukovac, M.J. 1963. Wide angle crotches are essential for structural strength in apple trees. Annu. Rpt. Mich. State Hort. Soc. 93:63-67.

Glenn, D.M. and W.V. Welker. 1993. Water transfer diminishes root competition between peach and tall fescue. J. Amer. Soc. Hort. Sci. 118:570574.

Horsfall, F., Jr. 1932. Winter injury to the crotch and trunk of the apple tree. Proc. Amer. Soc. Hort. Sci. 29:85-89.

Parker, M.L., J. Hull, and R.L. Perry. 1993. Orchard floor management affects peach rooting. J. Amer. Soc. Hort. Sci. 118:714-718.

Skene, K.G.M. 1975. Cytokinin production by roots as a factor in the control of plant growth, p. 365396. In: J.G. Torrey and D.T. Clarkson (eds.). The development and function of roots. Academic, London.

Verner, L. 1938. The effect of a plant growth substance on crotch angles in young apple trees. Proc. Amer. Soc. Hort. Sci. 36:415-422.

Warner, J. 1991. Rootstock affects primary scaffold branch crotch angles of apple trees. HortScience 26:1266-1267.

Welker, W.V. and D.M. Glenn. 1991. Growth response of young peach trees to distribution pattern of vegetation-free area. HortScience 26:1141-1142.

Westwood, M.N. 1978. Temperate-zone pomology. W.H. Freeman and Co., San Francisco. p. 116121.

Williams, M.W. and H.S. Billingsley. 1970. Increasing the number and crotch angles of primary branches of apple trees with cytokinins and gibberellic acid. J. Amer. Soc. Hort. Sci. 95:649-651. 